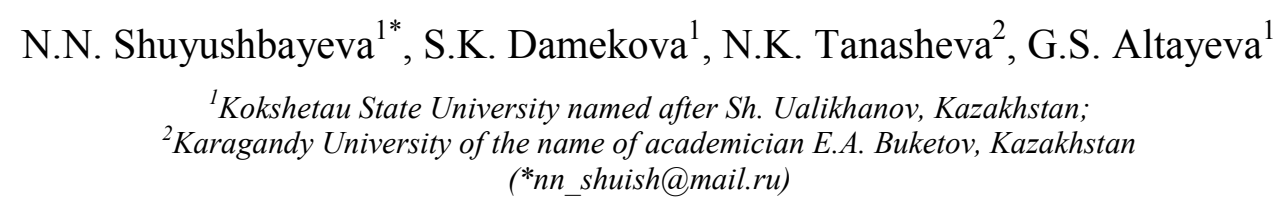

\title{
Formation of ICT competencies for future physics teachers
}

\begin{abstract}
The article discusses effective ways to use IT-services in teaching future physics teachers. This reflects the mutual understanding between the teacher and the student based on the use of modern information technologies in the development of the modern educational process. Some IT-services in teaching meet modern requirements. But this does not mean the chaotic use of any platform, programs, and software applications, that is, it is necessary to take into account the specifics of the subject, the pedagogical and psychological state of students. Based on this, the article describes what digital competencies should be used in the training of future physics teachers. Video lectures and audio lectures, infographics, visual lectures made in Mindmap, and Vyond on the discipline "Methodological basis of solving physical tasks" have a great influence on the comprehensive search of students. The article analyzes the necessity and relevance of using information technologies in the educational process but also discusses ways to implement them practically. This creates skills for students to use digital competencies to expand their knowledge. There are also ways to conduct questionnaires, tests, and reflections in various formats that allow students to test their knowledge. The types of tasks created in the effective applications used in the teaching of physics are given.
\end{abstract}

Keywords: IT-services, ICT competencies, methods of teaching physics, platforms, interactive learning, infographics, requirements, tasks.

\section{Introduction}

Currently, there is a huge potential of modern information technologies. It is necessary to adapt the education system to the digital generation through the mass and effective use of innovative educational technologies and didactic models based on ICT, thereby allowing everyone to study with the help of any teacher, wherever they are, using the latest available devices (computer, laptop, tablet, phablet, smartphone, etc.). At the same time, it is necessary to actively use the research approach in teaching aimed at developing students' qualifications and skills of scientific research in the formation of creative thinking and creative abilities based on IT competence. But it should be noted that information and communication technologies are not the solutions to all problems in the education system, they are a tool that can make lectures and seminars more information accessible and attractive for the digital generation.

Teachers retain their crucial role in the interactive learning process, focused on the needs of students. Thus, the authority of the teachers and the effectiveness of his activities won't depend on the level of mastering the course content and their pedagogical abilities but also on the extent to which they used modern information and communication technologies for collecting, processing, and teaching specific educational material. In other words, education should be redefined and the educational paradigm should be changed in the digital age because students do not want to learn traditionally, and teachers should not continue to teach traditionally [1].

\section{Methods}

The main methods of the research are the theoretical analysis of the problem status on the basis of the literature and the study of normative documents, observation, conversation, and interview.

The purpose of the study is to study the effectiveness of the integrated use of digital resources and services in the discipline "Methodological foundations for solving physical tasks" in the formation of ICT skills of future physics teachers to achieve this goal, the following tasks were set:

- analysis of digital resources and services in physics, creating conditions for achieving learning outcomes in the discipline "Methodological foundations for solving physical problems";

- creation of digital teaching aids in the discipline «Methodological foundations for solving physical tasks»; 
- experimental verification of the formation of ICT skills of future physics teachers in the process of studying the course «Methodological foundations for solving physical tasks».

In the education system of Kazakhstan, the issue of ICT competence of teachers is relevant, which can be discussed by analyzing the content of the adopted and developed regulatory legal acts in recent years, in particular, we are talking about the State Program "Digital Kazakhstan" [2].

UNESCO has developed the document "ICT Competence Framework for Teachers. UNESCO Recommendations, version 3". The recommendations include the competencies necessary for teachers in their professional activities, covering six main aspects of teachers' work: understanding the role of ICT in education, curriculum and assessment, pedagogical practices, ICT technical and software tools, organization and management of the educational process, professional development [3].

The concept of ICT skills in the scientific literature of G.V. Soldatova reflects modern requirements for the skills and abilities of members of the information society and is understood as based on the continuous mastering of competencies (knowledge, skills, motivation, responsibility) the ability of an individual to confidently, effectively, critically and safely choose and apply information and communication technologies in different spheres of life (information environment, communications, consumption, techno sphere), as well as his readiness for such activities [4].

Nowadays, Information Computer Technologies in educational institutions of the Republic of Kazakhstan are being implemented and actively implemented in the learning process through modern platforms and distance learning programs. For example, universities of the country use platforms such as Moodle (modularoriented dynamic learning), Microsoft Teams - Microsoft office workspace, Zoom, Google Meet, and Google Hangouts. Let's focus on the characteristics and capabilities of these platforms.

Moodle (modular-oriented dynamic learning). This open web application is a free e-learning system designed to organize the teaching and learning process for students and teachers. In this system, you can use all formats of documents, images, video, and audio files, as well as the SCORM archive [5].

Moodle, combined with a functionally rich test module, also allows you to evaluate students' work through such elements of the course as "Task", "Forum", etc. The results of the task can be evaluated on scales selected independently or passed by the teacher. On the forum, together with other participants of the course, you can configure the wiki, glossary, evaluation of articles or responses.

Moodle has great opportunities in creating tests, conducting training, and control tests. The tests use a wide variety of questions, such as a variety of choices, matching, correct/incorrect, short answers, essays, etc. Moodle is equipped with flexible tools for statistical analysis of semi-automatic testing results, which makes it easier to process tests.

Microsoft Teams is a Microsoft office workspace. It is a corporate platform that combines conversations, meetings, notes, and attachments in a workspace and is designed for remote teamwork. A workspace that allows users to collaborate, edit files and add notes wherever they are, helping them create a team, collaborate, and communicate instead of email [6].

It also allows teams to group messages to track video conversations, so that group conversations are usually visible to the entire group, or move to individual conversations. During voice and video conferences, participants create documents, videos, and audio files in the workspace where can actively use emojis, stickers, GIFs.

Microsoft Teams platform allows creating a calendar plan, scheduling classes, creating thematic groups and channels and uploading and downloading data and documents.

Zoom platformprovides video conferences, online meetings, and distance learning. A free account allows us to communicate via video conferencing for 40 minutes. Conferences of all sizes and up to 100 people have an unlimited duration [7].

The program is perfect for individual and group classes, students can log in both from a computer and a tablet by phone. Anyone with a link or conference ID can join the video conference. The event can be planned, as well as a duplicate link, that is, you can create the same login link for a regular lesson at a certain time.

Video and audio communication with each participant. The organizer can mute and turn on the microphone, as well as mute the video, also to start video with the only member of the conference with the right to review.

It is convenient to record a lecture both on a computer and in the cloud, and it can be paused by setting up the automatic recording. During the conference, there is an opportunity to assign a co-organizer with the 
same features as the organizer: for individual students, changing the name to turn on and off the microphone and dividing the room will help to perform group work.

Google Meet, Google Hangouts, Discord. Previously, Hangouts is used as a meeting, the presence of a limit on the number of participants is not profitable to use this platform. Google Meet is a video conferencing solution for corporate groups provided by Google [8]. It's the Google version of Zoom, with three levels of Basic, Business, and Enterprise that match the G Suite levels. However, Google Meet is available to anyone who has a Google account, so it is free for the public, with no time limit for up to 100 participants. In Google Meet, Google sits next to chat as part of a business communication solution, and Google Chat is an alternative to a service like Slack.

At the technological stage of modern education, there are also enough programs that allow creating tasks in different forms to conduct questionnaires, tests, and reflection to test students' knowledge in different formats. Some of them should be particularly noted.

Using Quizlet, teachers can create quizzes for students to complete control tasks, fill out suggestions, compare images and information, or choose the right answers. It is very easy to use - in a few minutes understand the interface, as well as work on Android and iOS on smartphones and tablets [9].

Kahoot! allows to submit all educational materials in the form of questionnaires and tests. Combined with a more detailed test of knowledge in a game format around new topics in the form of simple questions and answers to establish feedback with students. Kahoot! represents a new generation of student-response systems that has a main focus on student motivation and engagement through gamification [10].

Kahoot! - the teacher displays the material on the main screen, during which students answer questions and discuss information using a special application for computers or a browser on smartphones (Android, iOS, Windows Phone). For accessing the virtual cabinet, students must enter a special code sent by the teacher. This service allows you to find out how each student answered questions or create an academic performance schedule for the entire class. They can track the results themselves in special tables. Kahoot! free and fully available program after registration.

The main feature of Easy Test Maker is the ability to create tasks where the students need to select correct and false statements to format texts for easy reading on a tablet, or for testing in a traditional format .pdf. or download it in doc. formats [11]. This program can mix questions and answers to help students complete their tasks and allow them to create 25 Tests without the possibility of exporting the free version of Easy Test Maker to "paper" format.

In addition to creating questionnaires with different response formats in ClassMarker, students can also write an essay [12]. To get started, the teacher must create a virtual class and send invitation codes to students. ClassMarker stores the results of all tests performed, a statistical report. If the teacher has their own web page, they can add tests to it. In the free version, ClassMarker allows you to create no more than 100 Tests.

SurveyMonkey is a service for creating simple and small surveys, as well as distributing mass surveys, identifying trends, and creating large surveys [13]. The service allows you to create surveys, adjust their appearance, move questions, conduct two-answer A/B tests, conduct surveys on websites and social networks, create visual reports, protect data and combine MailChimp, GroSocial, CleverReach, and other tools.

Socrative is a tool for creating, finding, and distributing online tests for educational institutions, conducting tests [14]. Among the advantages, it is worth noting the simplicity and pleasant interface of development.

The analysis of scientific and methodological literature $[15,16]$ has shown that video lectures created in accordance with didactic requirements are not enough to organize training in the discipline "Methodological basis of solving physical tasks".

General didactic requirements for the volume of educational video lectures for use in the educational process, it is recommended to create video recordings of lectures, the playback time of which is no more than 10 minutes.

When creating a specially prepared training video, the following techniques were used to improve the perception of information, recommended in:

- Titles and sound savers fixing the semantic parts of the video lecture.

- Video materials that set the appropriate visual range (video illustrations, etc.).

- Close-ups of diagrams, images and use of infographics.

- Change of large and general plans of the lecturer to maintain attention to the emotions that the lecturer conveys through gestures and facial expressions. 
The use of video lectures in teaching allows students to activate mental activity, change the channels of perception of information from auditory to visual and vice versa. This type of lecture is accompanied by demonstration materials: presentation, video on the topic under study, diagrams, mind-maps, infographics, which are additional sources of information.

When the amount of information that needs to be remembered is measured in several pages, then such a method of presenting information and at the same time a method of teaching as a mind map is used. They represent a tree-like structure in the center of which is the central concept (lecture topic, complex object, end result or solution). Branches of secondary concepts depart from the central block.

Infographics are a type of visual presentation of data that is very effective in explaining and presenting various processes. Its main advantage is its colorful and laconic presentation of information.

However, it is important that the teacher knows the individual characteristics of students' perception of information. It is necessary to give the student the opportunity to choose tasks on an informational and figurative basis of various types. It increases the level of perception of educational information by students and contributes to their assimilation of the content of the academic discipline. This will contribute to the practical and professional implementation of the acquired knowledge and skills.

You can record video and audio lectures in various programs, including Microsoft PowerPoint, oCam, Audacity, and Bandicam, according to how students perceive and master the material (Fig. 1).

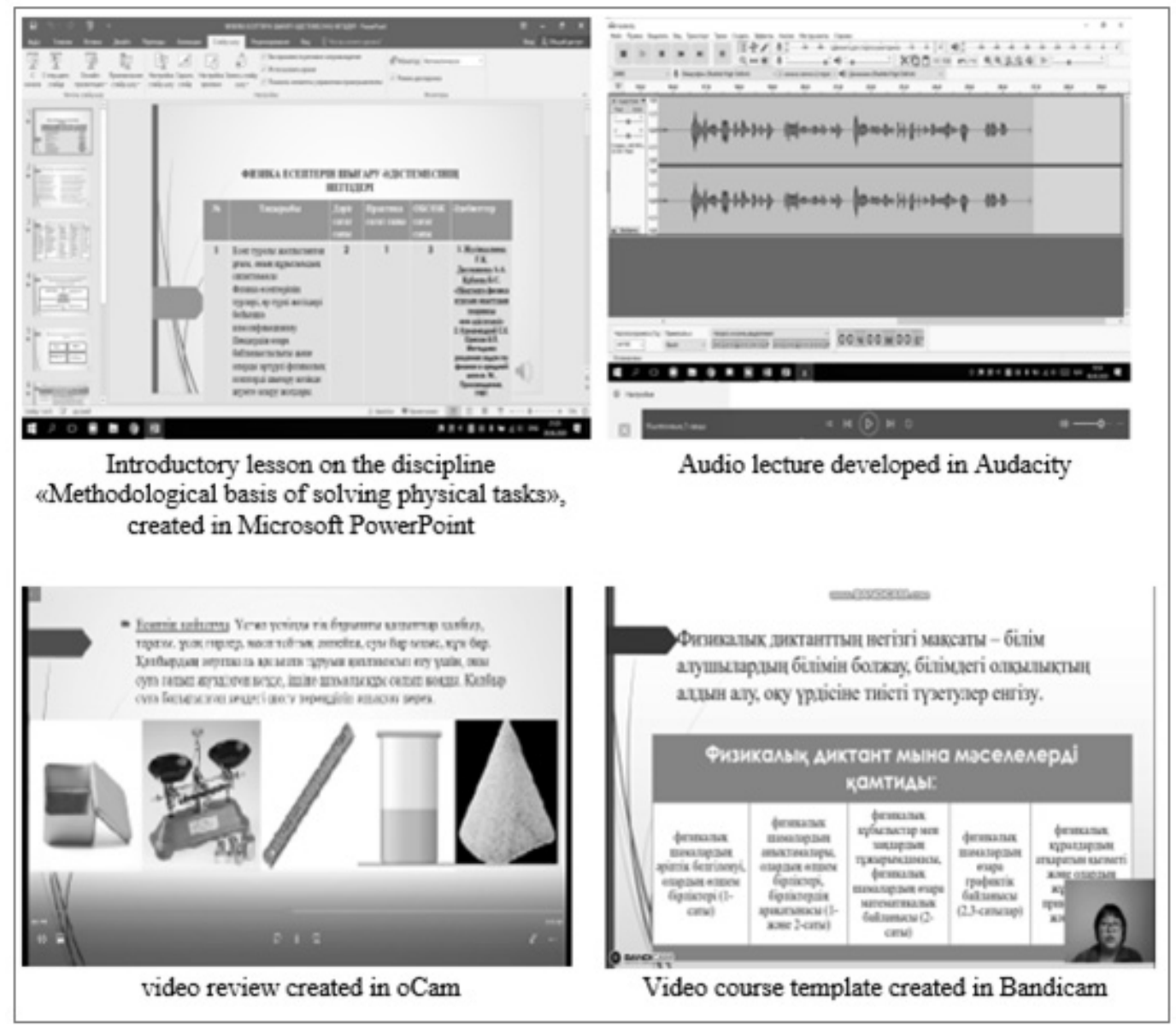

Figure 1. Video and audio training samples

Infographics are a graphical way of transmitting information [17]. Simply put, infographics allow you to organize the design of your educational materials so that they are easy and understandable to the student. This shows that infographics also include elements other than images, that is, they include text, diagrams, and blocks. In general, infographics are designed for fast, visual, and vivid delivery of material. For example, infographics are designed to explain the topic "algorithmization of methods for solving problems" is shown in Figure 2. 


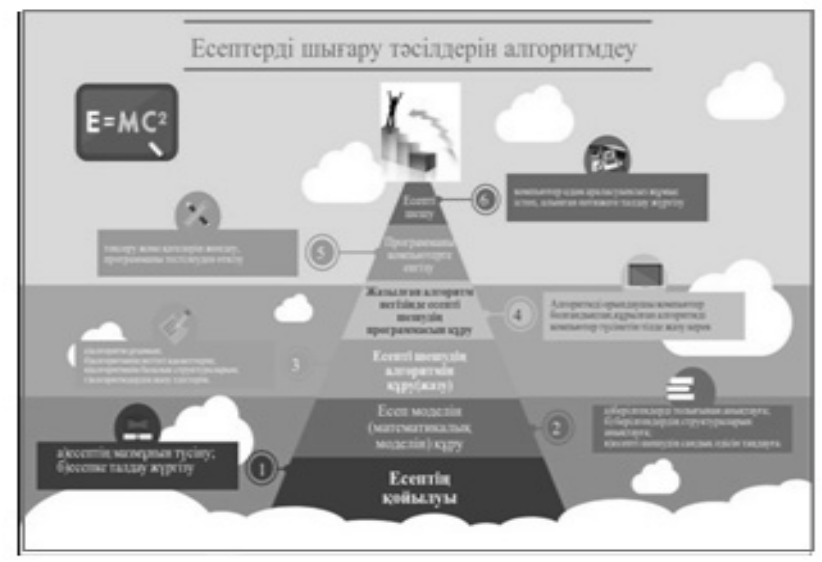

Figure 2. Infographics «Algorithmization of problem solving methods»

In fact, data can always be transmitted through text, tables, and numbers. But with the help of infographics, you can make sure that interpretation has the following advantages:

- infographics allow you to quickly convey to the audience a large number of materials in teaching physics. What you will have to read for a long time can be shown in one or more images;

- good infographics make information much clearer. Images are perceived by the human brain better than text;

- a bright, interesting picture will help attract the attention of the audience. Therefore, this format is used in public speaking, as well as in the media, and is used in modern textbooks.

In accordance with modern requirements, the updated curriculum can be clearly seen in physics textbooks of grades $7-11$, created using infographics.

Mind-map-Intelligence Map or mind map. It reflects the opportunities for reflection, memory, memory, and the ability to demonstrate an effective way to solve creative problems, as well as to present and visually demonstrate internal processes of Information Processing, make changes to them and improve them.

In the discipline "Methodological basis of solving physical tasks" one of the ways to explain the topic "ways to solve text problems" was prepared on the Mind-map map. In the first step, you need to highlight the main point. The creation of a thought map begins precisely in the middle, that is, in the middle of it, "Ways to solve text problems" is written. This indicates that the main idea or goal is set. In the second step, it is necessary to highlight the topics that come from the main idea and differentiate the materials necessary for understanding. It is chosen "the mathematical path" and "experimental path" according to the topic. When drawing a map, you should use different colors. In the third step, select additional topics and highlight additional topics that will help you better understand or follow the main topic. At this time, methods were proposed, which are considered on the mathematical and experimental line. The fact that all of them lead to the main idea can be clearly seen on the map (Fig. 3). The general Mind-map should be designed at any time in the center, at the edge of the eye, so that everything else is noticed and every detail is remembered.

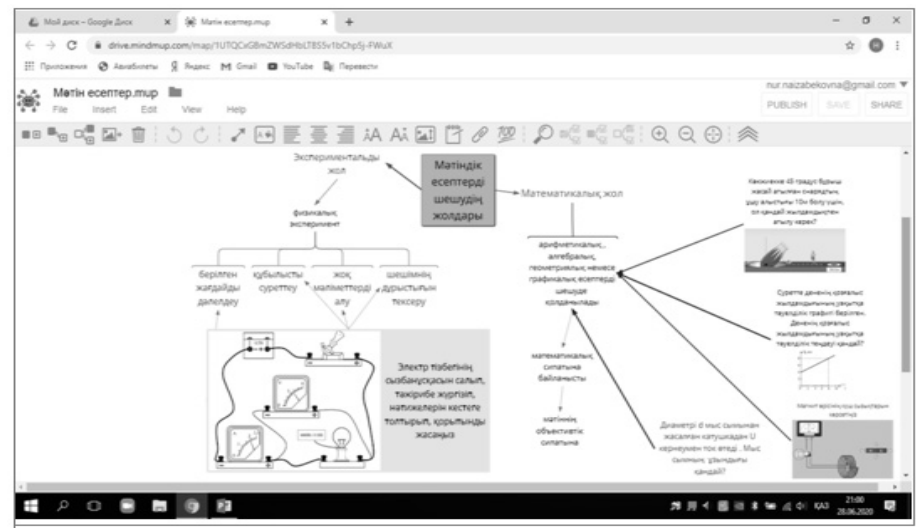

Figure 3. Mind-map on the topic "Ways to solve text problems" 
You can also use interactive features, including in the Vyond program, to create educational material in the form of "sketch animation" (Fig. 4). It not only increases the student's interest but also allows you to independently create moving scenes, i.e. animations. The free sample is saved only for 14 days.

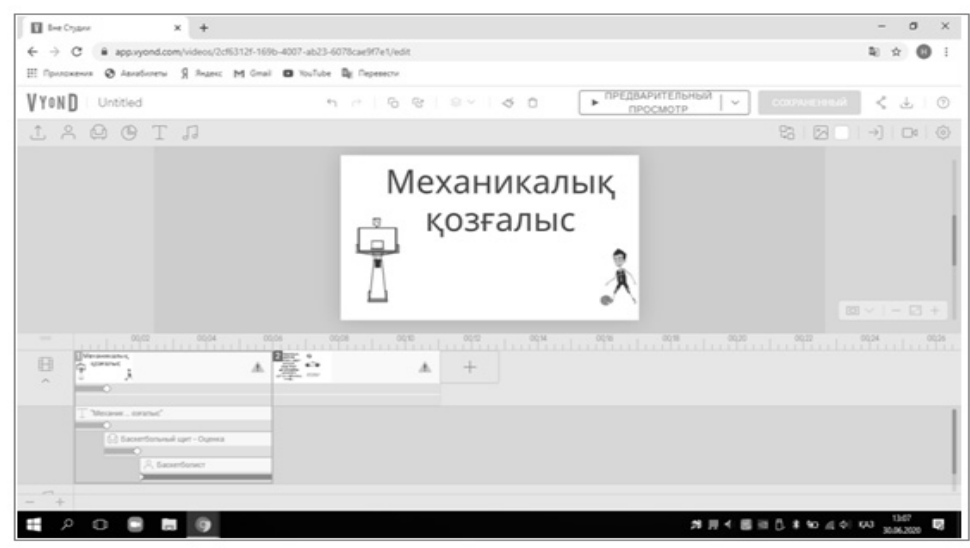

Figure 4. Sketch animation on the topic «Mechanical movement»

You can use the elements and resources of the electronic course for self-preparation of students. You can download lectures, presentations, videos, and test tasks on the discipline "Methodological basis of solving physical tasks" (Fig. 5). It will also be possible to adjust the time interval and determine the results of the training.

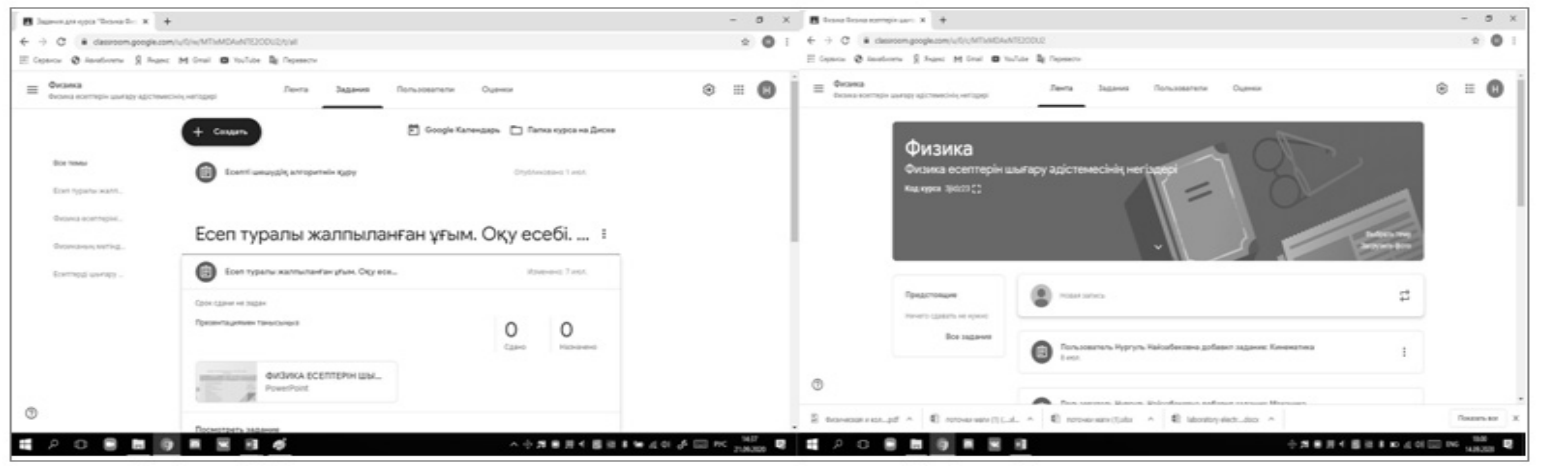

Figure 5. Elements of the electronic course on the discipline "Methodological basis of solving physical tasks" https://classroom.google.com/u/0/c/MTIxMDAxNTE2ODU2

To determine the level of knowledge of students, it is more effective to use the Survey Monkey and Socrative applications. Because in teaching physics, formulas, graphs, and demonstration of practical tasks are difficult to implement in other applications such as Kahoot, Class Marker, Easy Test Maker, and Google Forms. And these programs can only be used to test theoretical questions and tasks with answers such as "true" and "false".

It is very effective to conduct online and offline physics classes, quizzes, test tasks, and competitions through Socratic. In this app, you can create a lot of text and logical questions and provide feedback, which can be implemented using applications for mobile devices that do not require registration. In addition to getting an instant result for the teacher and student, it can store tests and their results in the app, mail, and computer.

During the period of the diagnostic experiment at Kokshetau State University, the level of ICT competencies of students of future physics teachers was assessed. To assess the level of students' ICT competencies, an interactive test was developed, in which students were asked to complete various tasks, answer questions related to the search, processing, and presentation of information. 59 students of Kokshetau State University took part in the test, the test was carried out among 3-year bachelor students in 2019-2020 full-time and distance learning. The indicator of the formation of students' ICT competencies is a low level of $18 \%$, an average level of $34 \%$, and a high level of $48 \%$ (Fig. 6). 


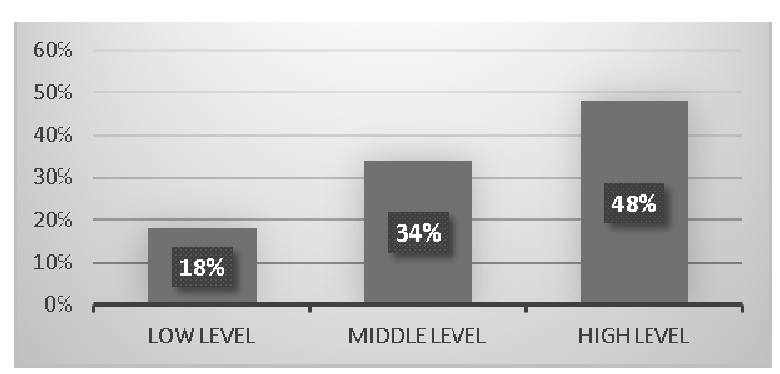

Figure 6. Levels of formation of ICT competencies

The results obtained in the course of diagnosing the level of ICT competencies of future physics teachers allowed us to conclude that the level of formation of ICT competencies is low.

An experimental check of the formation of IT competencies, in the course of studying the course "Methodological Foundations of Solving Physical tasks", was carried out on the basis of assessment tools developed in the Survey Monkey and Socrative applications.

To determine the level of knowledge of students, it is more effective to use the Survey Monkey and Socrative applications. Because in teaching physics, formulas, graphs, and demonstration of practical tasks are difficult to implement in other applications such as Kahoot, Class Marker, Easy Test Maker, and Google Forms. And these programs can only be used to test theoretical questions and tasks with answers such as "true" and "false".

It is very effective to conduct online and offline physics classes, quizzes, test tasks, and competitions through Socrative (Fig. 7). In this app, you can create a lot of text and logical questions and provide feedback, which can be implemented using applications for mobile devices that do not require registration. In addition to getting an instant result for the teacher and student, it can store tests and their results in the app, mail, and computer (Fig. 8).

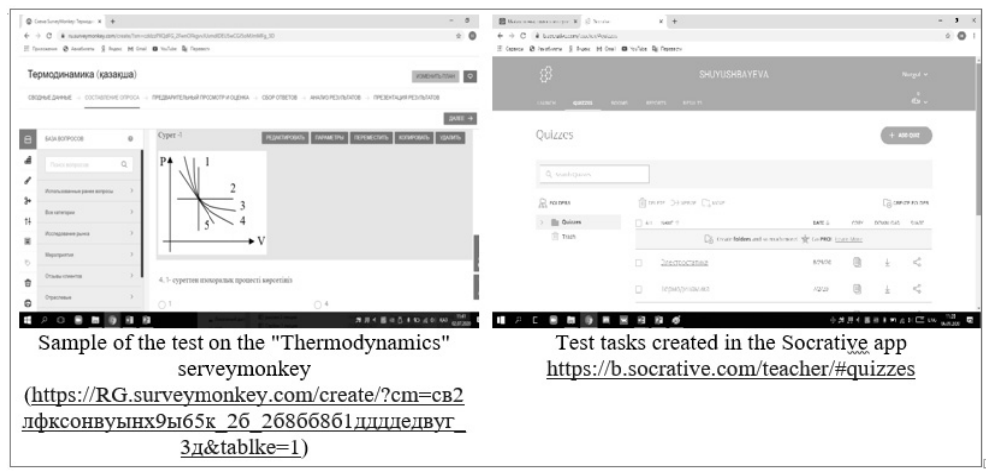

Figure 7. Shows the test results obtained from students in the Socrative app. In a short time, the assessment of students' knowledge was carried out

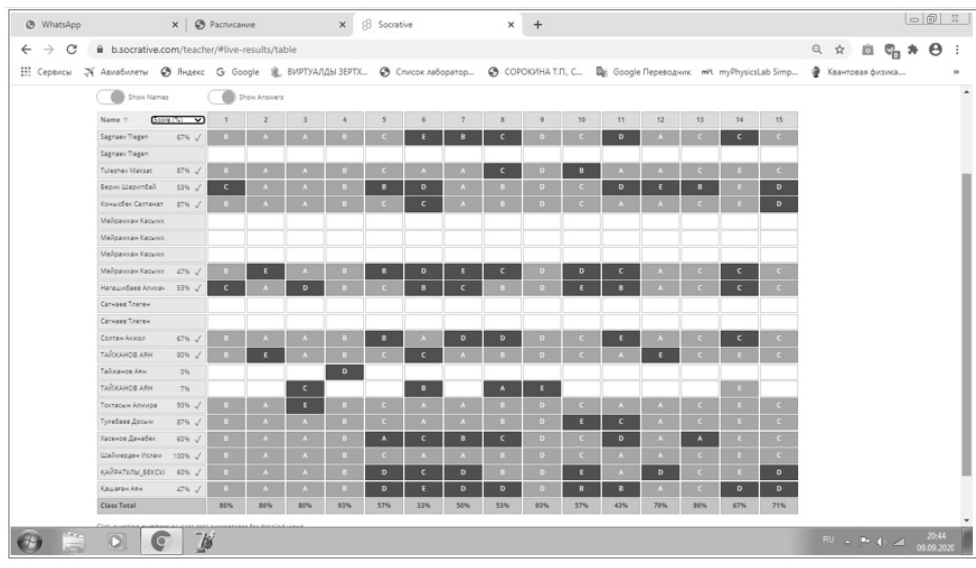

Figure 8. Test results obtained from students in the Socrative app 
As part of the experiment to determine the formation of IT competencies, in the course of studying the course "Methodological foundations for solving physical tasks", a survey was conducted, which showed that social networks and mobile messengers are the most popular means of communication among the respondents, therefore, they also have good potential as a platform for communication for educational purposes, for instant notification, dissemination of information among a group of users.

Many students, future physics teachers have shown a high willingness to master the techniques of working with information and information technologies, since a sufficient understanding of the capabilities of Kahoot, Class Marker, Easy Test Maker, and Google Forms, Survey Monkey and Socrative, incl. and for self-education, about the possibilities of automating various educational activities. The communicative component was also formed at a sufficient level, the students gained experience of participating in videoconferences, webinars, streams, and gained knowledge about the culture of Internet communication. Students willingly undergo training, participate in forum discussions, in group work, high daily attendance of distance learning.

\section{Conclusion}

The use of the above computer programs, services created by the authors of the video lectures in the course "Methodological foundations for solving future physics teachers of physical tasks" increased the interest of students in the use of digital technologies in educational activities, intensified the independent work of students using various electronic means of educational and developmental purposes; stable skills of using computer technology and skills of working with it were formed.

Finally, the conditions in the modern world meet various modern requirements of society, as a result of the use of advanced information and communication, electronic, digital, and computer technologies and models of life in cyberspace, there is a need for a high level of literacy that meets the needs of the information society. They should contribute to increasing the intellectual activity of future physics teachers, the formation of creative and mental abilities, the development of a worldview of the individual, which will allow him to take a strong position in the information society. Thus, the use of IT-services in teaching physics has a huge impact on students' self-education.

\section{References}

1 Жоғары және жоғары оқу орнынан кейінгі білім беру жүйесін цифрлық ұрпаққа бейімдеу тұжырымдамасы [Электронды ресурс]. — URL: https://www.enu.kz/downloads/yanvar-2020/hiedtech-kontseptsiya-kaz.pdf

2 State program "Digital Kazakhstan”[Electronic resource]. — URL: https://digitalkz.kz/razvitie-chelovecheskogo-kapitala/

3 UNESCO ICT Competency Framework for Teachers_[Electronic resource]. - URL: https://iite.unesco.org/ru/publications/ 3214694-ru/

4 Солдатова Г.У. Психологические модели цифровой компетентности российских подростков и родителей / Г.У. Солдатова, Е.И. Рассказова // Нац. психол. журн. - 2014. — Т. 2(14). — С. 27-35.

5 Manyakhina V. Description of setting up and using Moodle / V. Manyakhina, A. Zolochevsky [Electronic resource]. URL: https://docs.altlinux.org/ru-RU/archive/4.1/html-single/school-server/moodle/index.html

6 Microsoft Teams [Electronic resource]. — URL: https://techexpert.ua/products/microsoft-teams/

7 Archibald M.M. Using Zoom Videoconferencing for Qualitative Data Collection: Perceptions and Experiences of Researchers and Participants / M.M. Archibald, R.C. Ambagtsheer, M.G. Casey, M. Lawless // International Journal of Qualitative Methods. - 2019. - Vol. 18. - P. 1-8.

8 Google Meet [Electronic resource]. — URL: https://gsuite.google.ru/intl/ru/products/meet/

9 What is Quizlet? [Electronic resource]. — URL: https://quizlet.com/ru/teachers

10 Wang A.I. The effect of points and audio on concentration, engagement, enjoyment, learning, motivation, and classroom dynamics using Kahoot! / A.I. Wang, A. Lieberoth // Proceedings of the European Conference on Games-based Learning (2016, January). - 2016. - P. 738-746.

11 Easy Test Maker [Electronic resource]. — URL: https://easytestmaker.com/

12 The Best Quiz Maker for Business \& Education [Electronic resource]. — URL: https://www.classmarker.com/

13 SurveyMonkey [Electronic resource]. — URL: https://www.surveymonkey.ru/

14 Badanov A.G. Socrative Teacher manual / A.G. Badanov // Google Presentation [Electronic resourse]. - URL: https://docs.google.com/presentation/d/11q6_blwNxL-G8A8v4Q0WAtT9qXvOHd38cqQKiEpJq18/edit\#slide=id.p

15 Garnaeva G.I. Information and communication technologies competence formation of the future teacher of physics / G.I. Garnaeva, E.I. Nizamova, E.D. Shigapova // European Proceedings of Social and Behavioural Sciences: 4th International Forum on Teacher Education (2018, September). — 2018. - P. 221-227. 
16 Nekrasova G.N. Preparing Technology Teachers for Professional Activities in the Information Space of Technological Education / G.N. Nekrasova, N.N. Novikova // 5th International Forum on Teacher Education (IFTE) (2019, May). — 2019. - P. 473485.

17 Ferreira J. Infographics: An introduction. Technical Report [Electronic resourse] / J. Ferreira. — Coventry University, 2014. — URL: https://www.researchgate.net/publication/266082644

\title{
Н.Н. Шуюшбаева, С.К. Дамекова, Н.К. Танашева, Г.С. Алтаева
}

\section{Болашақ физика мұғалімдерінің цифрлық құзыреттіліктерін қалыптастыру}

\begin{abstract}
Мақалада болашақ физика мұғалімдерін оқытуда цифрлық сервистерді қолданудың тиімді жолдары қарастырылған. Бұл қазіргі заманғы білім беру үрдісін дамытуда заманауи ақпараттық технологияларды қолдану негізінде оқытушы мен студент арасындағы өзара түсіністікті көрсетеді. Оқытудағы кейбір цифрлық сервистер қазіргі заман талабын қанағаттандырады. Бірақ бұл кез келген платформа, бағдарламалар және бағдарламалық қосымшаларды бейберекет пайдалану дегенді білдірмейді, яғни пәннің ерекшелігіне, білім алушылардың педагогикалық-психологиялық жағдайларын ескеруді қажет етеді. Осы айтылғандар негізінде мақалада болашақ физика мұғалімдерін оқытуда қандай цифрлық сервистерді қолдану қажеттігі баяндалған. «Физика есептерін шығару әдістемесінің негіздері» пәні бойынша видеодәрістер мен аудиодәрістердің, инфрографикалардың, Mindmap және Vyond-та жасалған көрнекі дәрістердің студенттердің жан-жақты ізденуіне зор ықпал ететіні келтірілген. Мақалада оқыту үдерісінде ақпараттық технологияларды қолданудың қажеттілігі мен өзектілігі талданып қана қоймай, практикалық түрде іске асыру жолдары қарастырылған. Бұл студенттерге өз білімдерін кеңейту мақсатында цифрлық сервистерді пайдалану дағдыларын қалыптастырады. Сонымен қатар білім алушылардың білімін тескеруге мүмкіндік беретін әр түрлі форматта сауалнамалар, тесттер, рефлексия өткізудің жолдары айтылған. Физиканы оқытуда қолданылатын тиімді қосымшаларда жасалған тапсырмалардың түрлері келтірілген.
\end{abstract}

Кілm сөздер: ақпараттық технологиялар, цифрлық құзыреттіліктер, физиканы оқыту әдістемесі, платформалар, интерактивті оқыту, инфографика, талаптар, тапсырмалар.

\section{Н.Н. Шуюшбаева, С.К. Дамекова, Н.К. Танашева, Г.С. Алтаева}

\section{Формирование цифровых компетенций будущих учителей физики}

\begin{abstract}
В статье рассмотрены эффективные способы использования цифровых сервисов в подготовке будущих учителей физики. Это отражает взаимопонимание между учителем и учеником, основанное на использовании современных информационных технологий в развитии современных образовательных процессов. Некоторые цифровые компетенции в обучении соответствуют современным требованиям. Однако это не означает хаотичного использования какой-либо платформы, программ и программных приложений, то есть необходимо учитывать специфику дисциплины, педагогическое и психологическое состояние студентов. Исходя из этого, авторами отмечено, какие цифровые сервисы следует использовать при подготовке будущих учителей физики. Кроме того, видеолекции и аудиолекции по дисциплине «Методические основы решения физических задач», инфографика, наглядные лекции по Mindmap и Vyond имеют большое влияние на комплексный поиск студентов. В статье не только проанализирована необходимость и актуальность использования информационных технологий в учебном процессе, но и предложены способы их реализации на практике, способствующие развитию у студентов навыков использования цифровых сервисов для расширения своих знаний. Также представлены способы проведения анкет, тестов, размышлений в различных форматах, позволяющих проверить знания и навыки студентов. Приведены типы заданий, созданные в эффективных приложениях, используемых в преподавании физики.
\end{abstract}

Ключевые слова: информационные технологии, цифровые компетенции, методика преподавания физики, платформы, интерактивное обучение, инфографика, требования, задачи.

\section{References}

1 Zhohary zhane zhohary oqu ornynan keiinhi bilim beru zhuiesin tsifrlyq urpaqqa beiimdeu tuzhyrymdamasy [The concept of adaptation of higher and postgraduate education to the digital generation]. www.enu.kz Retrieved from https://www.enu.kz/downloads/yanvar-2020/hiedtech-kontseptsiya-kaz.pdf [in Kazakh].

2 State program "Digital Kazakhstan". digitalkz.kz Retrieved from https://digitalkz.kz/razvitie-chelovecheskogo-kapitala/

3 UNESCO ICT Competency Framework for Teachers. iite.unesco.org Retrieved from https://iite.unesco.org/ru/publications/3214694-ru/ 
4 Soldatova, G.U., \& Rasskazova, E.I. (2014). Psikholohicheskie modeli tsifrovoi kompetentnosti rossiiskikh podrostkov i roditelei [Psychological models of digital competence in Russian adolescents and parents]. Natsionalnyi psikholohicheskii zhurnal National Psychological Journal, 2(14), 27-35 [in Russian].

5 Manyakhina, V., \& Zolochevsky, A. Description of settings and use of Moodle. docs.altlinux.org Retrieved from https://docs.altlinux.org/ru-RU/archive/4.1/html-single/school-server/moodle/index.html

6 Microsoft Teams. techexpert.ua Retrieved from https://techexpert.ua/products/microsoft-teams/

7 Archibald, M.M., Ambagtsheer, R.C., Casey, M.G., Lawless, M. (2019). Using Zoom Videoconferencing for Qualitative Data Collection: Perceptions and Experiences of Researchers and Participants. International Journal of Qualitative Methods, 18, 1-8.

8 Google Meet. gsuite.google.ru Retrieved from https://gsuite.google.ru/intl/ru/products/meet/

9 What is Quizlet? quizlet.com Retrieved from https://quizlet.com/ru/teachers.

10 Wang, A.I., \& Lieberoth, A. (2016) The effect of points and audio on concentration, engagement, enjoyment, learning, motivation, and classroom dynamics using Kahoot! Proceedings of the European Conference on Games-based Learning, (pp. 738-746).

11 Easy Test Maker. easytestmaker.com Retrieved from https://easytestmaker.com/

12 The Best Quiz Maker for Business \& Education. www.classmarker.com Retrieved from https://www.classmarker.com/

13 SurveyMonkey. www.surveymonkey.ru Retrieved from https://www.surveymonkey.ru/

14 Badanov, A.G. Socrative Teacher manual. docs.google.com Retrieved from https://docs.google.com/presentation/ d/11q6_blwNxL-G8A8v4Q0WAtT9qXvOHd38cqQKiEpJq18/edit\#slide=id.p.

15 Garnaeva, G.I., Nizamova, E.I., \& Shigapova, E.D. (2018) Information and communication technologies competence formation of the future teacher of physics. European Proceedings of Social and Behavioural Sciences: $4^{\text {th }}$ International Forum on Teacher Education (2018, September). (pp. 221-227).

16 Nekrasova, G.N. \&Novikova, N.N. (2018) Preparing Technology Teachers for Professional Activities in the Information Space of Technological Education. 5th International Forum on Teacher Education (IFTE) (2019, May). (pp. 473-485).

17 Ferreira, J. (2014). Infographics: An introduction. Technical Report. Coventry University. www.researchgate.net Retrieved from: https://www.researchgate.net/publication/266082644 